\title{
A multifaceted analysis of the relationship between daily temperature of river water and air
}

\author{
Renata Graf ${ }^{1}$ (1)
}

Received: 15 August 2018 / Accepted: 1 April 2019 / Published online: 5 April 2019

(C) The Author(s) 2019

\begin{abstract}
The aim of the study was to establish the strength and direction of the relationship between daily temperature of river water and air with the use of selected estimation methods. The relationship was assessed for the River Noteć and its tributaries (Western Poland), using the cross-correlation function and Granger causality. The study established cause-and-effect relations for "water-air" and "air-water" directions of influence. It was confirmed that forecasting the pattern of flowing water temperature from changes in air temperature yields better results when done based on data from the previous day. Results of modelling the relationship between data series with the use of the linear and natural cubic splines models confirmed the presence of a nonlinear relation. It was also established that there is a statistically significant correlation of random fluctuations for both temperature series on the same days. This made it possible to confirm the occurrence of short-term connections between water and air temperature. The results can be used to determine the qualities of thermal regimes and to predict temperature of river waters in the conditions of climate change.
\end{abstract}

Keywords Cross-correlation $\cdot$ Granger's causality $\cdot$ Natural cubic splines model $\cdot$ Linear model $\cdot$ Water temperature $\cdot$ Air temperature

\section{Introduction}

Being prepared for climate change, the symptoms of which include an increase in air temperature and the temperature of river waters, constitutes one of the main challenges for the monitoring and assessment of the ecological state of waters and the management of water resources (Bolker et al. 2009; Arismendi et al. 2014). The thermal characteristics of waters have considerable ecological and practical significance for the economic utilisation of rivers (Allan and Castillo 2007). The temperature of river waters is a good indicator of climate change and of the degree of control of processes occurring in aquatic systems (Conlan et al. 2005; Olden and Naiman 2010; Padilla et al. 2015; Jackson et al. 2016; Letcher et al. 2016).

Renata Graf

rengraf@amu.edu.pl

1 Department of Hydrology and Water Management, Institute of Physical Geography and Environmental Planning, Adam Mickiewicz University in Poznan, Bogumiła Krygowskiego 10 str, 61-680 Poznan, Poland
The temperature of river waters is subject to daily, seasonal, annual, and multi-annual change, which is the result of the impact of climatic factors, river supply conditions, thermal characteristics of tributaries, and anthropogenic factors, e.g. the inflow of wastewater, thermal pollutants, and hydromorphological changes occurring within the channel of the water course (Sinokrot et al. 1995; Caissie 2006; Webb and Nobilis 2007; Graf 2018). The specific utilisation of the catchment area and the selected method of development of the river valley may also modify the thermal characteristics of river waters (Younus et al. 2000; Wiejaczka 2007; Gallice et al. 2015; Lisi et al. 2015).

The modelling of changes in river water temperature and its relationship with air temperature is conducted on various time and space scales (Caissie 2006; Arismendi et al. 2014; Hilderbrand et al. 2014). These dependences have been confirmed at various time resolution levels, taking into consideration the nature of short-term, medium-term, and long-term fluctuations (Webb et al. 2003; Sahoo et al. 2009; Toffolon and Piccolroaz 2015). Research into the relationships between river water and air temperature is conducted using genetic and statistical models. These are developed not only in relation to air temperature, but also as a function of 
the transfer of heat originating from groundwaters and the exchange that takes place in the hyporheic zone. Thermal energy is exchanged primarily on the air-water level, and to a lesser extent on the river bed-water level (Sinokrot and Stefan 1994; Caissie 2006).

The statistical methods used for analysing the thermal characteristics of waters and their relationships with air temperature range from simple linear regression equations to more complex parametric and nonparametric methods (Benyahya et al. 2007; Letcher et al. 2016). A multifaceted analysis makes it possible to determine the structure of connections and interdependences existing between water and air temperature (strength, form, and direction of the relationship), and forecast the relationship between variables. For the purpose of predicting the temperature of river waters, deterministic models make use of the energy balance (Sinokrot and Stefan 1994; Benyahya et al. 2007), whereas regression and stochastic models employ air temperature data (Caissie et al. 2004; Hilderbrand et al. 2014; Li et al. 2014). Due to their good forecastability, they are used for predicting changes in water temperature in the context of climate change (Neumann et al. 2003; Webb et al. 2003; Lagergaard Pedersen and Sand-Jensen 2007). Analyses are concerned primarily with the nature and strength of the relationship between water and air temperature measurement series, and also with the synchronicity of their fluctuations. Good results are obtained, among others, through the logistic regression model, which approximates the dependence by means of an S-shaped function. This model effectively reflects the behaviour of water temperature at negative and high (in excess of $25^{\circ} \mathrm{C}$ ) air temperature. Its application has made it possible, among others, to confirm that the strength of logistic and linear relationships between river water and air temperature is greater for average weekly values and average maximum weekly values than for average daily values or maximum daily values (Neumann et al. 2003).

The majority of studies result in high determination coefficients $\left(R^{2}>0.8\right)$, which point to the high dependence of water temperature on air temperature (Pilgrim et al. 1998; Caissie et al. 2001; Webb et al. 2003; Morrill et al. 2005). Research into the thermal regime of Polish rivers also confirms the high impact of air temperature on the course and variability of river water temperature. Goodness-of-fit values of models for the lower River Świder calculated by Łaszewski (2014) are similar to the goodness-of-fit values obtained by the aforementioned authors. When analysing the relationship between air temperature and water temperature in the River Ropa, Wiejaczka (2007) determined that this relationship is very strong, which is confirmed by the fact that the corresponding coefficient of correlation ranges from 0.90 to 0.95 . The coefficient of correlation between water temperature in the River Ropa and air temperature in winter half-year periods alternated between 0.75 and 0.89 , whereas in the summer half-year periods the value of this coefficient was slightly greater, fluctuating from 0.85 to 0.95 . In the winter half-year periods following the commissioning of the Klimkówka reservoir on the River Ropa, there occurred a noticeable increase in the value of the coefficient of correlation (0.80-0.89), while in the summer half-year periods it was observed that its value fell to the range of 0.61-0.87. According to Wiejaczka (2011), linear regression makes it possible, among others, to estimate the value of water temperature in rivers under conditions of increased air temperature brought about by potential climate changes, and also to determine the reach of subterranean supply and its impact on the thermal characteristics of rivers. Kędra and Wiejaczka (2016) have conducted an analysis of changes in the natural relations between the water temperature of the River Dunajec and air temperature based on values of the Pearson correlation coefficient. This research has shown that the dependences between the analysed variables in the years 1978-1992, i.e. before the group of reservoirs was commissioned, were stronger during the summer period (coefficient of correlation of 0.75-0.86) and weaker in winter (coefficient of correlation of 0.54-0.73). Following the erection of the Czorsztyn-Sromowce Wyżne reservoirs, values of the coefficient of correlation fell to the range of $0.53-0.77$ in the summer half-year period, while in the winter half-year period the strength of the relationship grew to $0.60-0.82$. The application of a model describing the dependence between water and air temperature by means of a linear function has proved useful in the case of the River Warta (the middle section of its course) for the range of temperatures from $0.5-1.0{ }^{\circ} \mathrm{C}$ to approximately $22-23{ }^{\circ} \mathrm{C}$ (Graf 2015). The analysis confirmed that this relationship has a nonlinear form which is most significantly impacted by the behaviour of water temperature at negative air temperature values or during periods of long-term frost. When the air temperature is high, the temperature of water in rivers does not increase linearly, this because of the intense loss of thermal energy in processes of evaporation and emission of long-wave radiation (Graf 2015; Łaszewski 2014). Statistical significance was also demonstrated for the coefficient of correlation between air temperature and the water temperature of the River Warta along the section between Bobry and Skwierzyna in the years 1991-2010 (Graf et al. 2018). The coefficient assumed a high value, ranging from 0.74 to 0.83 at individual stations. The principal components analysis (PCA) of the natural variability of water temperature in surface waters of the Tatra Mountains confirmed the dependence of water temperature on weather conditions, catchment characteristics, and flow rate, explaining $88.97 \%$ of total data variability (Żelazny et al. 2018). The authors of these studies also confirmed that wavelet analysis is helpful in identifying cyclical patterns in water temperature time series. Furthermore, a number of studies were carried out 
of the mutual relations between water and air temperature in terms of the assessment of long-term tendencies of change therein taking into consideration climate change. As regards the Polish Lowland, a clear increase in air and inland water temperature was determined over longer periods, such as the year or half-year. In shorter periods (months), this increase is not always obvious, and sometimes even a fall in temperature was observed (Graf et al. 2018; Marszelewski and Pius 2018). The allochthonous character of rivers guarantees greater temperature stability of waters along their course, while the thermal characteristics of tributaries and spatial changes in the methods of their supply may contribute to a disruption of the thermal continuum.

Analyses of the interdependence of statistical features of water and air temperature also use multi-level regression modelling, such as-for example - the hierarchical linear model, which is known as the regression model for random effects (Hox 2002). This is elaborated on the basis of a division of measurement series into permanent and random effects, a multi-level data structure taking into consideration inter-level interaction, and a specific approach to variance components (Gelman and Hill 2006). An example is, among others, a hierarchical model of daily stream temperature using air-water temperature synchronisation, autocorrelation, and time lags, elaborated in a small stream network in western Massachusetts-USA (Letcher et al. 2016). The presented model limits analysis to days when air and water temperature is synchronised, accommodates hysteresis, incorporates time lags, can deal with missing data and autocorrelation, and can include external drivers. An interesting approach applied in research into the relationship between river water and air temperature is the hybrid model, which uses a hybrid formulation characterised by a physically based structure associated with a stochastic calibration of the parameters (Piotrowski and Napiórkowski 2018). This model has been utilised among others to predict daily averaged river water temperature as a function of air temperature and discharge in selected rivers in Switzerland (Toffolon and Piccolroaz 2015). The degree of consistency achieved for different model versions with measurements performed in the three rivers suggests that the proposed model may constitute a useful tool for synthetically describing the mediumand long-term thermal characteristics of waters, and also for capturing their changes caused by variable external conditions. Furthermore, spatial analyses of river systems make use of geostatistical models (Rushworth et al. 2015) and regional neural networks (Sahoo et al. 2009; DeWeber and Wagner 2014; Napiórkowski et al. 2014). Finally, assessments of the regularity of features of the thermal regime of rivers also utilise the equilibrium temperature concept (Caissie et al. 2005) and regional dependences connected with geographical latitude (Arscott et al. 2001; Gardner et al. 2003).
The study presents a multifaceted approach to the analysis of the relationship between daily river water and air temperature using selected estimation methods. The objective of research was to determine the character, strength, and direction of the relationship between observation series on the example of the River Noteć, which serves important economic and ecological functions (Western Poland, Polish Lowlands). For the purpose of assessing the relationship between data series, use was made of the cross-correlation function and its decay, while causality dependences were analysed in terms of Granger's causality (referred to as $G$-causality). Cause-and-effect relationships occurring on the "water-air" axes were also determined. As regards water and air temperature time series, the identification of causal patterns for the variance and the mean using Granger's causality analysis may serve to improve the quality of forecasting these values. Assuming a nonlinear relationship between water and air temperature data series, an indication was given of the usefulness and appropriateness for such research of the linear model and the natural cubic spline model.

\section{Source material and methodology}

\section{Test area}

Research into the dependences between daily river water and air temperature was conducted in the catchment area of the River Notec that drains the western part of the Polish Lowlands (Fig. 1). The Noteć is the largest tributary of the River Warta, which itself flows into the River Oder (a drainage area of the Baltic Sea). In the division of Poland into physico-geographical regions (Kondracki 2008), the catchment area of the River Noteć is located within the reach of two macroregions: the Wielkopolskie Lake District, through which the river flows in its main bed, and the Pomeranian Lake District, which is traversed by its two right-bank tributaries - the rivers Gwda and Drawa (Fig. 1). The catchment area is located primarily within the reach of two climatic regions: that of Western Wielkopolska and that of Eastern Wielkopolska (Woś 2010), where the mean annual air temperature amounts to $8.3^{\circ} \mathrm{C}$ and $8.0^{\circ} \mathrm{C}$, respectively.

There are numerous lakes along the course of the Noteć and its tributaries, and these occupy approximately $4 \%$ of the surface of the catchment area (Fig. 1). The river is regulated by means of a system of flood gates and channelled in its middle course, which impacts its hydrological features. The Noteć and its tributaries are characterised by a snowand-rain type supply. The greatest flows usually occur in March and April, when spring run-off accounts for some 130-180\% of annual run-off. Average annual specific runoff for the River Noteć in the Nowe Drezdenko profile is 


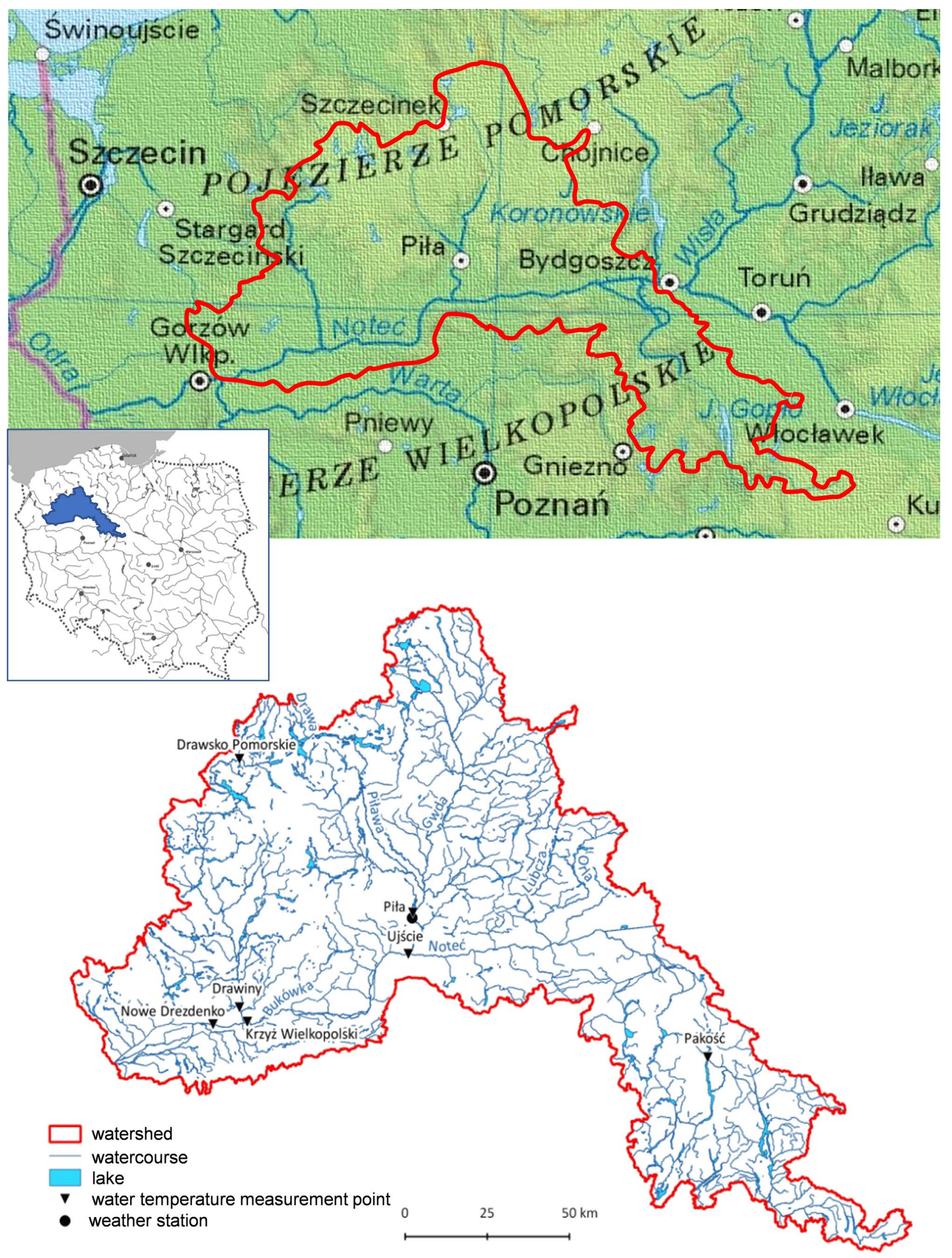

Fig. 1 Location of the Noteć catchment area in Polish regions with IMGW-PIB stations measuring water and air temperature 
$144 \mathrm{~mm}$ (according to IMGW-PIB data). The lowest flow values occur from July to September. Summer-autumn low waters are predominant in the Noteć and Drawa, and their average duration is longest, totalling 75 and 97 days, respectively. The river is characterised by considerable fluctuations of water levels, and their maximum spread in its lower course amounts to $3.5 \mathrm{~m}$.

Taking into consideration the abiotic type of river waters and their biotic typology (macrobenthic, phytobenthic, and macrophytobenthic), the River Noteć has been classified among the "great lowland rivers" (ETC/ICM 2015). The water course serves as a migration corridor for numerous species of fishes, while due to its excellent natural qualities the river valley has become the object of conservation measures, notably through the establishment of Natura 2000 areas (which include the "Noteć Valley" and the "Valley of the Middle Noteć and the Bydgoszcz Channel").

\section{Database}

When modelling the relationship between daily river water and air temperature, use was made of measurement data gathered by the Institute of Meteorology and Water Management-National Research Institute in Warsaw (IMGWPIB in Warsaw) for the period 1987-2013. These data contain daily water temperature of the River Noteć registered at three points located along its course: at Pakość (upper course), Ujście (middle course), and Nowe Drezdenko (lower course), and also along its tributaries, i.e. the Gwda (Piła profile) and the Drawa (Drawiny profile)—Fig. 1. For comparative purposes, use was additionally made of daily water temperature for the River Drawa at the point in Drawsko Pomorskie, albeit for a shorter measurement period (1987-1992). Daily air temperature for the years 1987-2013 was obtained from the Piła synoptic station located in the catchment area of the Noteć. Data concerning air temperature obtained at this station are homogenous. Series uniformity was confirmed using the Alexandersson test, and therefore, these data should be considered as representative for the research area and period. The choice of research period was influenced by the ability to access a uniform observation series of water and air temperature, uninterrupted by the lack of measurement values.

\section{Multifaceted modelling}

Modelling of the relationship between time series of daily temperature values was preceded by an assessment of data series stationarity, conducted using the Augmented Dickey-Fuller (ADF) test (Dickey and Fuller 1981). As regards the analysed data series (1987-2013), it was determined that daily measurements of water and air temperature constitute stationary series (stationarity at a $p$ value of 0.01 ) characterised by invariability when shifted along the time axis of the mean and the variance.

The point of departure for assessing the relationship between data series concerning daily temperature was an analysis of the cross-correlation function, which is the standard for determining the similarity of measurements. It uses value functions of the Pearson correlation coefficient for two time series shifted in relation to each other by time unit $\Delta t$ either forward or backward, depending on the value of $\Delta t$. In order to provide a quantitative description of the phenomenon of decaying cross-correlations, a determination was made of the decay function of the square of cross-correlation for measurements carried out on the same day in different years. This may be interpreted as the variance percentage of one variable explained by another variable for measurements made on the same day in different years. To this end, use was made of third-degree polynomial regression for the natural logarithm of the square of correlation, where the distance between measurements-counted in years-was a dependent variable.

Further, a Granger's causality analysis (Granger 1988) was performed, and this made it possible to identify the direction of cause-and-effect relationships between water and air temperature. The Granger's causality refers to a situation where data concerning the past of one time series provide significant information that helps predict the value of a second series, which is not included in the information concerning its past values. Research utilised the Granger's causality test (Detto et al. 2012), which was conducted for stationary processes. The general test determines solely whether a linear dependence exists. Granger's causality is a statistical approach used to identify the presence of linear causal interactions between time series of data, based on prediction theory. In accordance with the assumptions of causality (Granger 1988), which makes use of only two time series and does not reference the complete information set, variable $Y$ influences variable $X$ if:

$P(X t+1 \in A \mid X, Y) \neq P(X t+1 \in A \mid X)$ for a certain event $A$,

$X$-history of time series, $X, X, Y$-history of time series $X$, and $Y, X t+1$-value of the variable at moment $t+1$.

An analysis was also performed of the strength of the relationship between measurements of river water and air temperature on the same days, taking into consideration the possibility of occurrence of a nonlinear relationship between the two. To this end, use was made of two models-a standard linear model for predicting water temperature on the basis of air temperature and the natural cubic spline model. The degree of correlation between the random fluctuations of series, i.e. of those changes in temperature that are not the result of a long-term trend, historical values or periodicity, was also determined. It provided valuable insight into the 
characteristics of short-term connections between water and air temperature (Graf 2018).

$y_{t}=\varphi_{1} y_{t-1}+\varphi_{2} y_{t-2}+\varepsilon_{t}$

where $y_{t}$-series value at time $t, y_{t-1}$-series value at time $t-1$, etc., $\varepsilon_{t}$-random component, disturbance from time $t, t$-successive days, and $\varphi$-a parameter defining the strength of impact of the preceding value in the process (or successive ones, incrementally older) on the current value.

The above dependences were then used to determine the residues for time series of temperature, that is, that part of each measurement which may be considered as a random fluctuation. The analysis of residue series for models was augmented by means of Granger's causality. When determining the changes in coefficients of determination $\left(R^{2}\right)$ for models taking into consideration the past values of the second time series, an indication was given of the strength of cause-and-effect connections existing between them.

Calculations and statistical analyses were performed in the $\mathrm{R}$ calculation environment, version 3.3.2 (2016 October 31 ). The R suite (GNU R) is a software package for analysing data, and also a programming platform (R Core Team 2015). The results of the statistical significance tests used were assessed with reference to the adopted level of $\alpha=0.05$. Whenever a different level of significance was adopted, the relevant information was attached to the results of calculations.

\section{Results}

\section{Cross-correlations}

The analysis of cross-correlations demonstrated a very high degree of interdependence between daily data series of water temperature values for the Noteć and its tributaries, and air temperature values for the station in Piła (Fig. 2). We can clearly observe that significant positive correlations occur between daily temperature measured for the same half-year periods (cold or warm in the hydrological year), and significant negative correlations for measurements performed in different half-year periods. Equally visible is the gradual decay of process memory, i.e. measurements from successive years are less and less correlated. This means that for a zero shift we have a maximum level of interdependence between both data series. As the shift increases over time, cross-correlation adopts a minimal value.

As regards the measurement points located on the River Noteć and its tributaries, the rivers Drawa (in Drawiny) and Gwda (in Piła), a similar picture of the cross-correlation functions for daily water and air temperature was observed, and thus, Fig. 2a presents (as representative) the chart for the Noteć in Ujście (middle course). A high level of interdependence between series of daily water and air temperature, albeit lower and more rapidly decaying than that for the remaining stations, was demonstrated by an analysis of cross-correlations at the Drawsko Pomorskie point on the River Drawa. In this case, however, only a 12-year observation series of river water temperature was available (Fig. 2b).

For comparative purposes, the effect of cross-correlation was determined for monthly water temperature of the River Noteć and its tributaries, and for air temperature measured
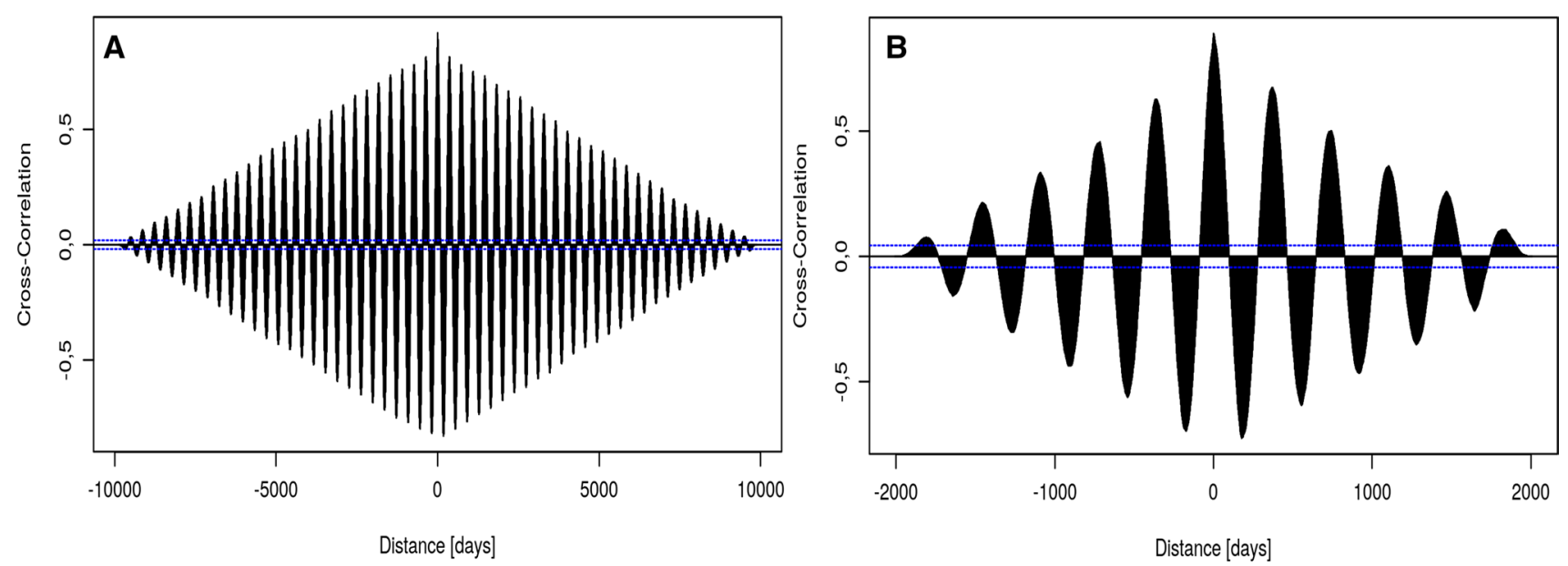

Fig. 2 Function of cross-correlations between daily water and air temperatures: a Noteć-Ujście (1987-2013) and b Drawa—Drawsko Pomorskie (1987-1991) 
in Piła. In this case, too, the ADF test showed that time series are stationary, while an analysis of cross-correlations confirmed a very high level of interdependence between data series (average monthly temperature measured for the same hydrological half-year periods-cold or warm), which are additionally strictly periodic in nature (Fig. 3a, b).

In order to more precisely investigate the phenomenon of decaying cross-correlations, a determination was made of the decay function of the square of cross-correlation for measurements carried out on the same day in different years. Using third-degree polynomial regression for the natural logarithm of the square of correlation, solutions were obtained that were very well matched to the data $\left(R^{2}\right)$-Table 1 . The coefficients of determination obtained were similar, falling within the range of 0.993-0.998 for the measurement series for the River Noteć, and totalling 0.997 for its tributaries. Clearly, therefore, the variance of variables registered in the water temperature measurement series is explained mainly by the variable temperature of air for measurements taken on the same day but in different years.

The decay function of the square of cross-correlation for measurements of river water and air temperature at individual measurement points located on the River Noteć and its tributaries is presented in Fig. 4. In the case of the River Gwda in Piła, due to the occurrence of problems with an unequivocal determination of the peaks of annual crosscorrelations, the model was constructed taking into consideration only distances of not less than 14 years (among others, a distance of 5 years was omitted). Despite this inconvenience, we can observe that the dependence is very similar to that occurring at other measurement points (Fig. 4).

\section{Granger's causality}

When using Granger's causality to analyse dependences between daily water temperature of the River Noteć and its tributaries and air temperature (station in Piła), it was determined a cause-and-effect relationship (Table 2).

Furthermore, the test was a first-order test, which means that the cause-and-effect relationship occurs already between measurements $t$ and $t-1$, where $t$ stands for the distance between measurements, which is counted in years. Granger's causality was determined taking into consideration a oneday lag.
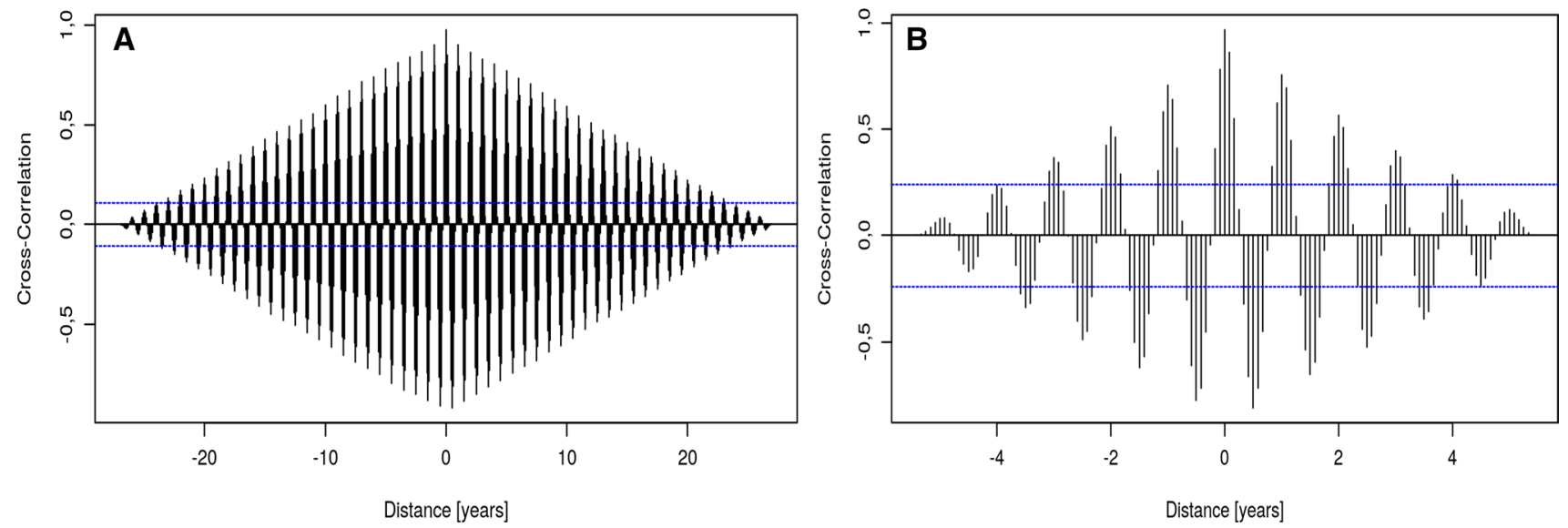

Fig. 3 Function of cross-correlations between monthly water and air temperatures a Noteć-Ujście (1987-2013) and b Drawa-Drawsko Pomorskie (1987-1991)

Table 1 Model of third-degree polynomial regression applied to the logarithm of a square of correlation between daily temperature of river water and air (Noteć River)

\begin{tabular}{lll}
\hline River-profile & Model of third-degree polynomial regression & $R_{\text {adj }}^{2}$ \\
\hline Noteć-Pakość & $\ln R^{2}=-0.13-0.20 t+0.015 t^{2}-0.001 t^{3}$ & 0.993 \\
Noteć-Ujście & $\ln R^{2}=-0.18-0.16 t+0.011 t^{2}-0.001 t^{3}$ & 0.998 \\
Noteć-Nowe Drezdenko & $\ln R^{2}=-0.11-0.21 t+0.016 t^{2}-0.001 t^{3}$ & 0.994 \\
Gwda-Piła & $\ln R^{2}=-0.2009-0.1380 t+0.0082 t^{2}-0.0005 t^{3}$ & 0.997 \\
Drawa-Drawiny & $\ln R^{2}=-0.157-0.189 t+0.014 t^{2}-0.001 t^{3}$ & 0.997 \\
Drawa-Drawsko Pomorskie $^{\mathrm{a}}$ & $\ln R^{2}=0.62-1.90 t+0.62 t^{2}-0.09 t^{3}$ & 0.997 \\
\hline
\end{tabular}

$t$ - distance between measurements in years, $R_{\text {adj }}^{2}$ adjusted parameter value

${ }^{a}$ Drawa-Drawsko Pomorskie: Lag order $=12$ (1987-1991), for other measurement stations: Lag order $=27$ (1987-2013), $\alpha=0.01$ 

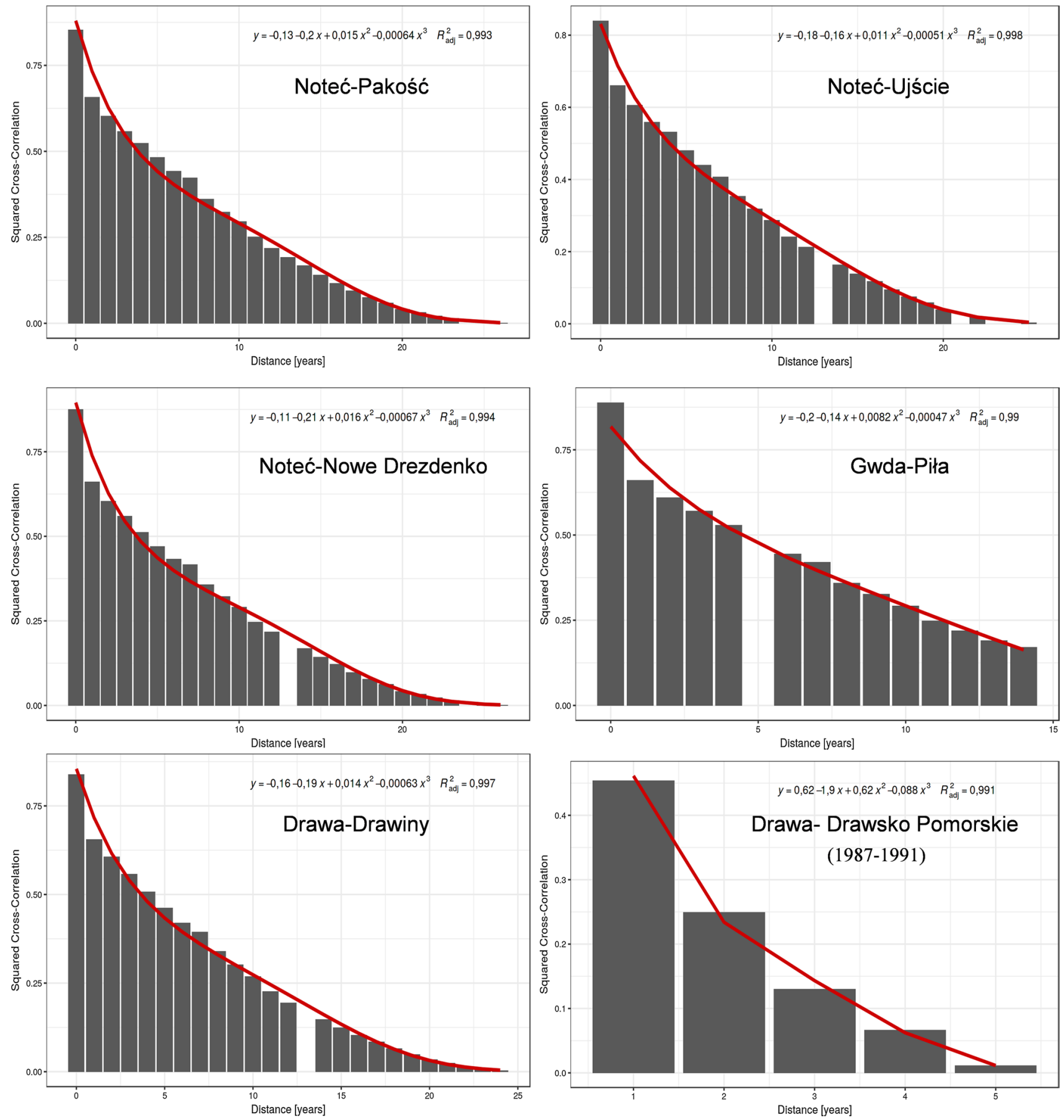

Fig. 4 Decay function of cross-correlation square for daily water temperature series (1987-2013)

Forecasting the course of water temperature fluctuations for the Noteć and its tributaries on the basis of changes in air temperature may therefore ensure better results if use is made of information from the preceding day. The hypothesis as to the dependence between water and air temperature series is confirmed by a variance analysis (test) which made use of the test statistic $F$. Table 2 presents the standard notation of the test result, with the numbers in parentheses representing degrees of freedom of distribution $F$, while the value on the right side of the "=" sign is that of the test statistic $F$. The results of the variance analysis indicate a considerable Granger dependence of water temperature on air temperature at $p<0.001$. The greatest impact was determined for the River Gwda at the station in Piła, which functions as a synoptic station. 
Table 2 Cause-and-effect relation between series of river water and air temperature in terms of Granger's causality

\begin{tabular}{ll}
\hline River-profile & Water-air \\
\hline Noteć-Pakość & $F(1,9859)=2901$ \\
Noteć-Ujście & $F(1,9859)=2476$ \\
Noteć-Nowe Drezdenko & $F(1,9859)=3685$ \\
Gwda-Piła & $F(1,9859)=5169$ \\
Drawa-Drawiny & $F(1,9859)=1823$ \\
Drawa-Drawsko Pomorskia $^{\mathrm{a}}$ & $F(1,2005)=53.91$ \\
\hline
\end{tabular}

$t$-distance between measurements in years

$F$ - test statistic, numbers in parentheses - degrees of freedom of distribution $F$, values on the right side of the "=" sign are those of the test statistic $F$

${ }^{a}$ Drawa-Drawsko Pomorskie: Lag order $=12$ (1987-1991), for other measurement stations: Lag order $=27(1987-2013), \alpha=0.01$

\section{Linear and natural cubic splines models}

An analysis of the strength of the relationship between measurements of the water temperature of the Noteć and its tributaries and air temperature, performed on the same days, was also carried out using the linear model and the natural cubic spline model-Fig. 5.

Results confirmed the existence a nonlinear relationship between them. In all instances, the linear model recreated water temperature variance to a lesser degree (78.65-88.02\%) than the natural cubic spline model (84.05-89.83\%). The differences between the models ranged from 3.96 to $4.73 \%$ and were statistically significant. The greatest difference $(5.67 \%$ ) was determined in the models elaborated for the River Drawa in Drawsko Pomorskie, which was connected with the fact that a shorter water temperature observation series (12 years) was adopted for modelling. A high degree of conformity was obtained in the model elaborated for the Noteć water temperature series at Nowe Drezdenko (Table 3).

\section{Prediction models}

The levels of significance of standard statistical tests are a decreasing function of the number of observations, and therefore, an attempt was made at carrying out an additional assessment of the strength of the connections found. To this end, it was determined for the present instance by how much the determination coefficient $\left(R^{2}\right)$ of both models increases after the past values of the second time series are taken into account. The model predicting the water temperature of the Noteć and its tributaries on the basis of water and air temperature from the preceding day (station in Piła) explains $0.01-0.27 \%$ more of the unique variance than the model which utilises solely water temperature from the preceding day (Fig. 6). In the present context, "unique variance" refers to the variance percentage that is explained by a given factor in addition to that which is explained by historical values of a given variable, i.e. in the case of water temperature-by previous temperature values. The greatest increase in the percentage of unique variance that is explained by the additional factor has been determined for the water temperature series of the River Gwda $(0.27 \%)$ and the River Notec at Nowe Drezdenko $(0.19 \%)$, and the lowest for the River Noteć in Ujście $(0.07 \%$, following the exclusion of data for the River Drawa in Drawsko Pomorskie)-Fig. 6. By way of comparison, the model predicting the average monthly water temperature of the River Noteć and its tributaries on the basis of water and air temperature from the preceding month explained $0.87-2.75 \%$ more of the unique variance than the model utilising solely water temperature.

The next stage of the analysis was concerned with determining the degree of correlation of random fluctuations (chance fluctuations) for the same days of both temperature measurement series. Random fluctuations were taken to be those changes in temperature that do not result from a long-term trend, historical values, or periodicity (Table 4). This provided valuable insight into the characteristics of short-term connections between water and air temperature. The occurrence of a statistically significant correlation was determined. Random fluctuations of air temperature explain from $1.8 \%$ (River Drawa at Drawiny) to $8.0 \%$ (River Noteć at Ujście) of random water temperature fluctuation variances.

Random events and values in the measurement series that are atypical for the thermal regime of river waters appear in consequence of various disorders of its course. An analysis of the degree of correlation between random fluctuations of water temperature series for the River Noteć and its tributaries and air temperature for the same days has confirmed the short-term nature of this connection.

The strength of cause-and-effect connections was studied on the basis of an analysis of changes in the coefficients of determination $\left(R^{2}\right)$ of models taking into consideration the past values of the second time series (Table 5). As regards fluctuations of water temperature, the greatest $R^{2}$ difference amounted to $9.98 \%$ (Drawa-Drawiny) in relation to $R^{2}$ equal to zero. This means that in the present instance fluctuations of air temperature have a significant and by no means small (for it explains nearly $10 \%$ of variability) impact on random fluctuations of water temperature on the next day. Furthermore, the regression coefficient-which determines the impact of air temperature fluctuations on water temperature fluctuationsindicates that this is a positive relationship: on average, positive deviations of air temperature are associated with positive deviations of water temperature on the next day, while negative deviations are associated with negative deviations on the next day. In the remaining models for predicting the water temperature of the Noteć and its tributaries, obtaining of a low $R^{2}$ value $(0.56-0.94 \%)$ taking into consideration the past values of the 

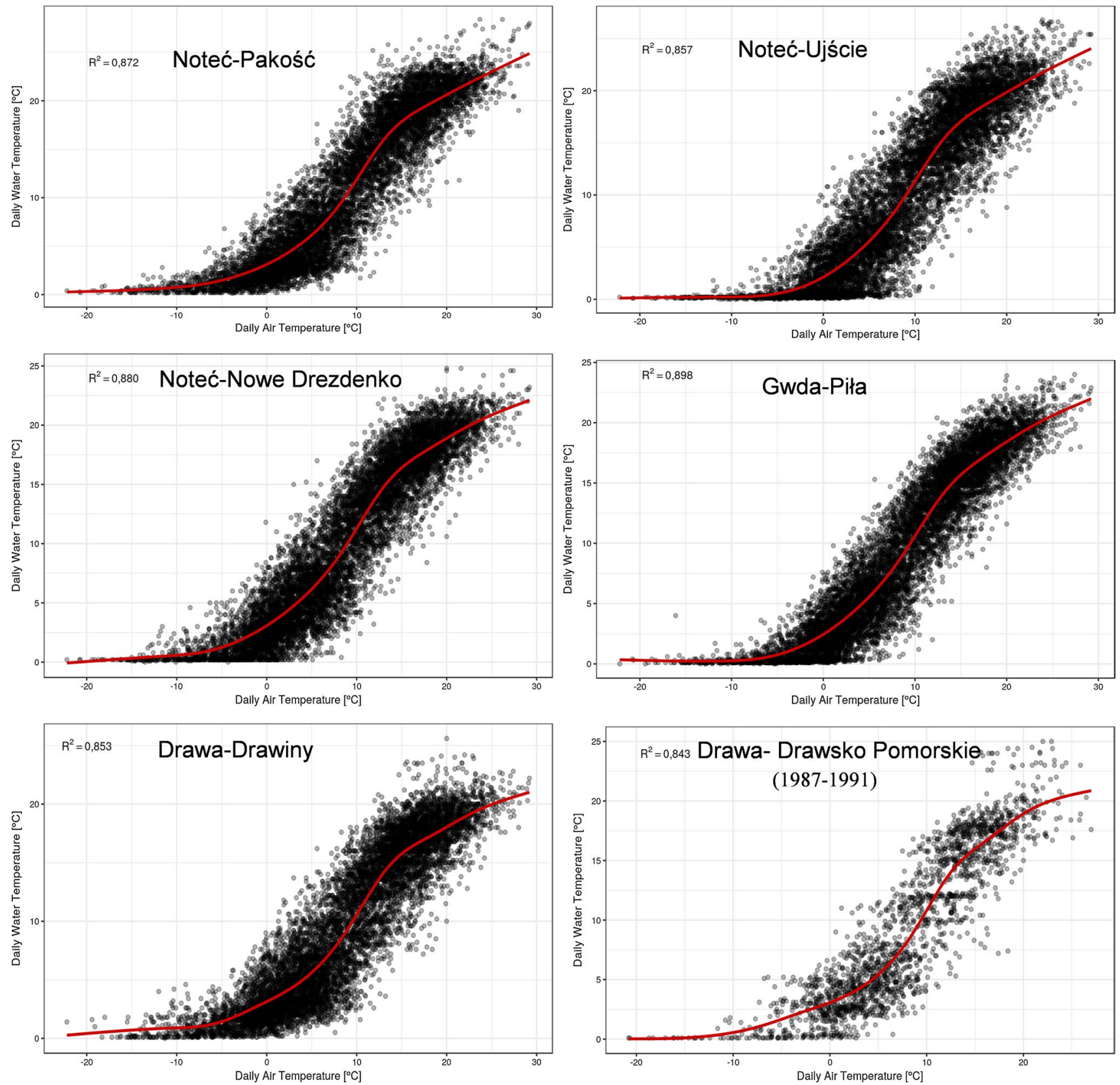

Fig. 5 Relationship between daily river water and air temperature (1987-2013) according to the natural cubic splines model

second time series, confirms that in this case water temperature fluctuations are relatively independent of each other and are not significantly impacted by air temperature fluctuations.

\section{Discussion}

\section{Cause-and-effect relations}

The existence of a relationship between fluctuations in river water temperature and air temperature has been confirmed under differing climatic and regional conditions (Bogan et al. 2003; Webb et al. 2003; Arismendi et al. 2014; DeWeber and Wagner 2014). In the case of the River Noteć and its tributaries, a high cross-correlation was established between daily water and air temperature, as well as Granger's causality. The results of analyses of cross-correlation between both variables, which are strictly periodic in nature, indicate clearly that process memory undergoes gradual decay, and this means that measurements from successive years are less and less correlated (Figs. 2, 3). This is confirmed by analyses of the decay function of the square of cross-correlation 
Table 3 Degree of recreating water temperature variances for the Noteć River and its tributaries using the linear and natural cubic splines models

\begin{tabular}{lllll}
\hline River-profile & Linear model (\%) & $\begin{array}{l}\text { Natural cubic splines } \\
\text { model }(\%)\end{array}$ & $\begin{array}{l}\text { Difference in variance recreation } \\
\text { between models }(\%)\end{array}$ & $\begin{array}{l}\text { Level of statistical } \\
\text { significance } p< \\
0.001\end{array}$ \\
\hline Noteć-Pakość & 82.44 & 87.17 & 4.73 & $F(4,9859)=907.5$ \\
Noteć-Ujście & 81.06 & 85.65 & 4.60 & $F(4,9859)=789.3$ \\
Noteć-Nowe Drezdenko & 88.02 & 84.05 & 3.96 & $F(4,9859)=814.7$ \\
Gwda-Piła & 85.68 & 89.83 & 4.15 & $F(4,9859)=1006$ \\
Drawa-Drawiny & 81.10 & 85.30 & 4.20 & $F(4,9859)=686.3$ \\
ánawa-Drawsko Pomorskie & 78.65 & 84.32 & 5.67 & $F(4,2005)=181.1$ \\
\hline
\end{tabular}

$\mathrm{F}$ - test statistic, numbers in parentheses—degrees of freedom of distribution $F$, value on the right side of the "=" sign are the values of test statistics $F$

${ }^{a}$ Drawa-Drawsko Pomorskie: Lag order= 12 (1987-1991), for other measurement stations: Lag order= 27 (1987-2013)

Fig. 6 Prediction models for the water temperature of the Noteć River and its tributaries (daily and monthly series) taking account of past values of the second time series $(t w-1)$ and increase in unique variance percentage explained by an additional factor $(\%)(t w-1)$ water temperature from the previous day/month $(\mathrm{m})$

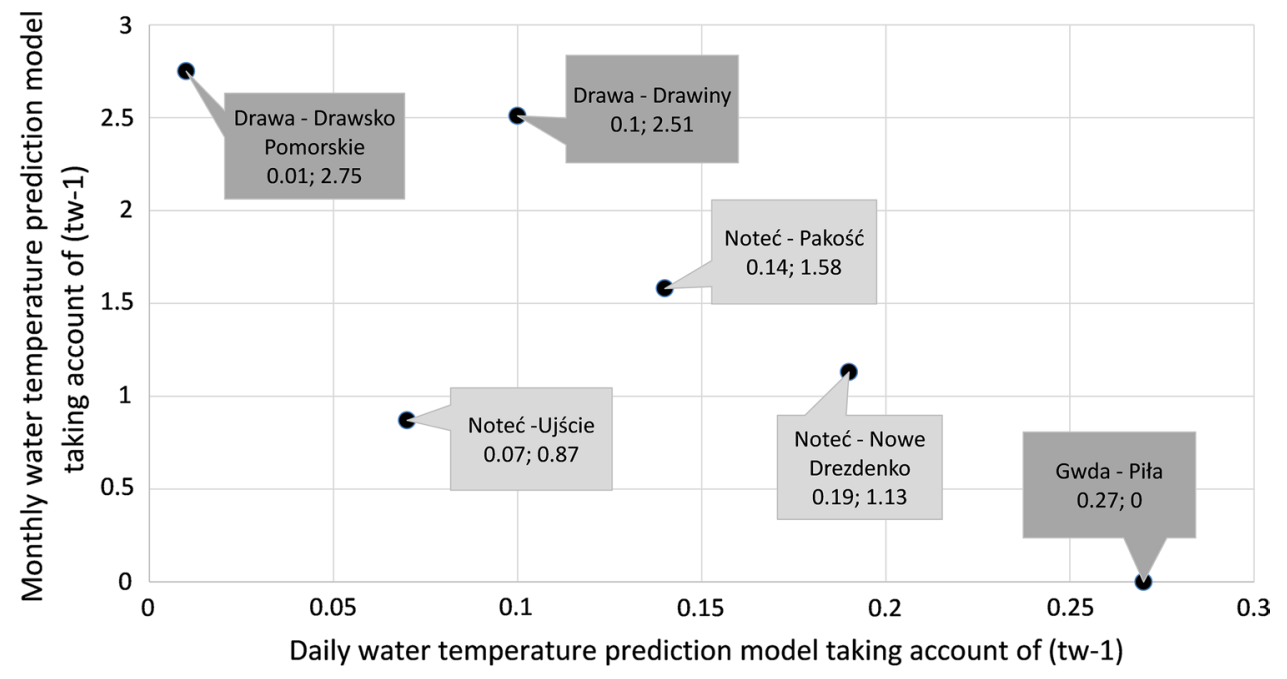

Table 4 Degree of linear correlation of fluctuations occurring in random series of river water and air temperature changes for the same days

\begin{tabular}{lll}
\hline River-profile & $\begin{array}{l}\text { Linear correlation of random fluctuations } \\
\text { for the same days (Pearson's } r)(p<0.001)\end{array}$ & $\begin{array}{l}\text { Degree of explaining } \\
\text { random fluctuation varia- } \\
\text { tions }(\%)\end{array}$ \\
\hline Noteć-Pakość & $r=0.24 ; t(9860)=24.22$ & 5.61 \\
Noteć-Ujście & $r=0.28 ; t(9860)=29.20$ & 8.00 \\
Noteć-Nowe Drezdenko & $r=0.22 ; t(9860)=22.15$ & 4.74 \\
Gwda-Piła & $r=0.22 ; t(9860)=22.12$ & 4.73 \\
Drawa-Drawiny & $r=0.13, t(9860)=13.23$ & 1.80 \\
Drawa-Drawsko Pomorskie & $r=0.121 ; t(2006)=5.48$ & 1.47 \\
\hline
\end{tabular}

$t$-number of days

${ }^{a}$ Drawa-Drawsko Pomorskie Lag order $=12(1987-1991)$, other stations Lag order $=27(1987-2013)$ for measurements carried out on the same day in different years (Fig. 4). The results of cross-correlation obtained for the River Noteć and its tributaries are of significance for the short- and medium-term assessment, concordant with seasonality or cycles (Liu et al. 2005; Toffolon and Piccolroaz 2015). In the short-term perspective, however, we should turn attention to the forecast and the deviation of the actual reading from the forecast. In the present instance, the cross-correlation was examined for the entire available time series of water and air temperature and did not take into consideration the specificity of individual thermal cycles. Neither to correlation connections explain the cause-and-effect 
Table 5 Increase in the coefficient of determination $\left(R^{2}\right)$ in models predicting random fluctuations of water temperature taking account of past values of the second time series $(t w-1)(\%)$

\begin{tabular}{ll}
\hline River-profile & $\begin{array}{l}\text { Prediction model for random fluctuations of } \\
\text { water temperature taking account of past values } \\
t w-1\end{array}$ \\
\hline Noteć-Pakość & $0.69(0.03)^{\mathrm{a}}$ \\
Noteć-Ujście & $0.56(0.03)$ \\
Noteć-Nowe Drezdenko & $0.76(0.03)$ \\
Gwda-Piła & $0.82(0.03)$ \\
Drawa-Drawiny & $9.98(0.00)$ \\
Drawa-Drawsko Pomorskie & $0.94(0.01)$ \\
\hline
\end{tabular}

$t$-number of days, $(t w-1)$ - water temperature from the previous day

Drawa-Drawsko Pomorskie Lag order $=12$ (1987-1991), other stations Lag order $=27$ (1987-2013)

a The brackets contain $R^{2}$ values for the model taking account of only the random fluctuation of water temperature from the previous day relationships between temperature, which can be achieved using the Granger's test. The determination of Granger's causality dependence (first order) between daily temperature series provides confirmation of the impact of one data series on the evolution of a second data series. In the analysed instance, data concerning the past of a time series of air temperature provide information that is of significance for predicting the values of the time series of river water temperature, which is not included in the information concerning its past values (Detto et al. 2012). In the context of Granger's causality, it is important to state that water temperature is determined causally by air temperature from the preceding day (Morrill et al. 2005; Letcher et al. 2016). These relationships occur mainly during water freezing and evaporation processes, which involve enormous quantities of energy. The latent heat of water phase transitions is collected from and given up to the environment (Hannah et al. 2004; Caissie 2006). In the local scale, these processes cause the significant heating or cooling of air above water courses and their immediate surroundings.

\section{Local factors affecting the stream temperature}

River thermal regimes are impacted first and foremost by the surface exchange of heat with the atmosphere in processes of radiation, evaporation, and convection (Caissie 2006), and also by the turbulent mixing of water of varying temperature, e.g. inflows, wastewater, thermal pollutants. It is assumed that molecular diffusion, the exchange of heat with the subsoil, and conductivity in the water mass play a less important role in shaping the thermal regime characteristics (Sinokrot and Stefan 1994). Local factors that modify the thermal characteristics of river waters usually include anthropogenic change (Olden and Naiman 2010), which may disturb the continuity of processes and the gradient nature of zones in rivers (the so-called river continuum) (Caissie et al. 2005). In the case of the catchment area of the River Noteć, local factors that impact its thermal regime include the specific morphological nature of the river valley-the flat, broad Torun-Eberswalde Glacial Valley, springs flowing from the edges and terraces of river valleys, and the proximity of peat bogs. Vast wetlands are present in the lower and middle courses of the River Noteć (Fig. 7). These wetlands contribute to the lowering of river water temperature in the summer period due to the supply to the river of groundwater of a considerably reduced temperature.

As regards the Noteć, one of the more significant causes of undesirable changes in flowing water temperature (Poole and Berman 2001; Lisi et al. 2015) may be the degraded morphology of the channelled sections of its course. This factor usually makes it difficult to recreate the historical thermal regime of a water course.

Numerous studies concerning the dependence between times series of water and air temperature have shown that the relationship between variables is not ideally linear (Langan et al. 2001; Wiejaczka 2007; Letcher et al. 2016). This is supported among others by the results of the natural cubic spline model, which was used in research-Fig. 5. First and foremost, this is connected with the fact that water temperature, as opposed to air temperature, has a lower limit and cannot attain a value of less than $0{ }^{\circ} \mathrm{C}$, even during periods of long-term frost. The impact of local factors modifying the thermal characteristics of river waters is also visible in the diversity of features of the winter ice regime (Graf and Tomczyk 2018; Graf et al. 2018). During the summer season, when air temperature is high, the temperature of water in the river does not increase linearly (Fig. 5), this because of the intense loss of thermal energy in processes of evaporation and emission of long-wave radiation. Changes in temperature in the aquatic environment occur at a considerably slower rate than changes in air temperature due to the lower conductivity of water in comparison with air.

Usually, a strong, nonlinear statistical dependence between the temperature of water and air is shown by the logistic (nonlinear) and linear regression models. Despite the nonlinear character of the dependence, the 


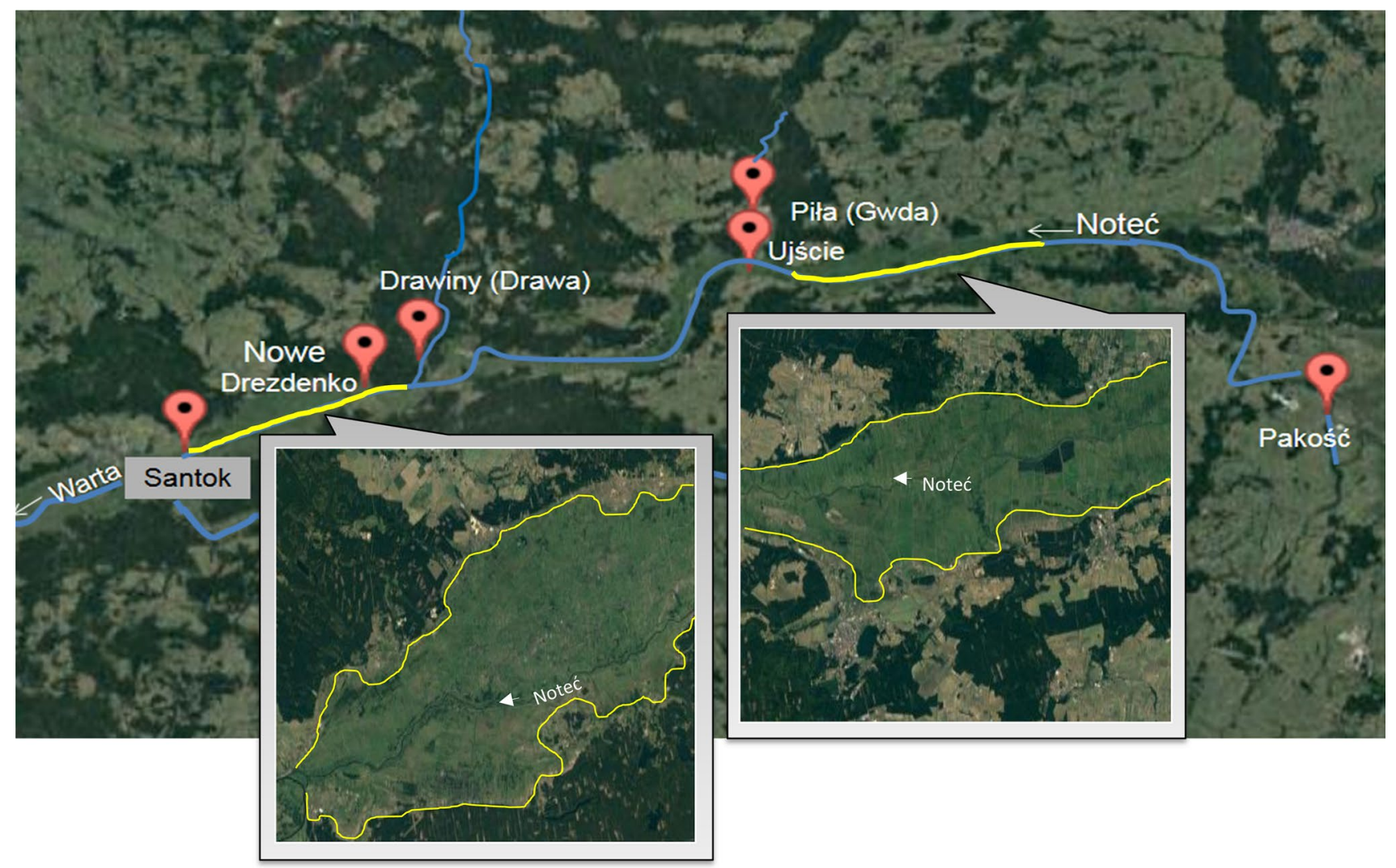

Fig. 7 Land coverage in the Noteć catchment area taking account of the extent of wetlands in the Torun-Eberswalde Urstromtal system-orthophotomap of the Noteć catchment area [based on http://web4you.com.pl/geofinder.php]

appropriate selection of measurement data makes it possible to effectively apply the linear model (Łaszewski 2014), which accurately reflects the connection between average monthly water and air temperature. In turn, this association is weakened by the following: daily averages, weekly averages, and maximum daily or weekly values of air temperature lower than $0.0{ }^{\circ} \mathrm{C}$ (Mohseni and Stefan 1999). The nonlinear form of dependence in the logistic model is described by the $S$-shaped function (sigmoidal) with input values from the range $(0,1)$, which properly reflects the behaviour of water temperature in the presence of negative and high (above $25^{\circ} \mathrm{C}$ ) air temperature (Mohseni et al. 1998; Neumann et al. 2003; Caissie et al. 2001; Łaszewski 2014), and this fact has indeed ensured the universality of application of the method. Among dependences approximated by logistic models, the strongest association was determined for the average weekly and average maximum weekly water and air temperature (Wiejaczka 2011), while the connection between the average daily and maximum daily water and air temperature (Webb et al. 2003; Morrill et al. 2005) turned out to be weakest. In turn, Zhu et al. (2018) while analysing three standard models-linear regression, nonlinear regression, and the stochastic-confirmed that the stochastic model clearly exceeds the other two. In stochastic models, water temperature is modelled as a function of time comprising two completely different components-a short-term residual component and a long-term component that is periodic in time (Caissie et al. 1998; Hadzima-Nyarko et al. 2014). Furthermore, in stochastic models water temperature is generally modelled as a function of time consisting of two entirely different components: a short-term residual component and a long-term component which is periodic in time (Zhu et al. 2018).

The natural cubic spline model used in research also confirmed the nonlinear dependence between river water and air temperature. The spline-based method resulted in an acceptable water time series temperature pattern that properly reflects its actual association with air temperature. Due to seasonal changes in water and air temperature, the model determining the dependence between them should ensure continuous seasonal patterns for each day throughout the year, and also the smooth periodicity of changes under specific boundary conditions. The spline technique additionally makes it possible to intercept the data trend irrespective of the character of the base relation, with the simultaneous reduction of the tendency to oscillate and of susceptibility to changes in data. Thus, we can use this method to, for 
example, supplement missing data, which frequently constitutes a significant problem in statistical research into water temperature measurement series.

\section{Data generating process (DGP)}

As regards water and air temperature time series, the identification of causal patterns for the variance and the mean using Granger's causality analysis may serve first and foremost to improve the quality of predictions of these values through the construction of models that take them into consideration. A narrowing of the interpretation concerns linear causality (for water-air temperature), whereas in the broader context we are concerned with the dependence of data generating processes (DGPs) (Cameron and Trivedi 2005). The concept of Granger's causality is not limited to the search for a variable whose presence in the model may improve the accuracy of forecasts. In line with the concept of causality, the cause in time series precedes the effect, while the causal series contains information about the variable being the effect, which was not included in other series (Granger 1988).

\section{Conclusions}

Research into the relationship between daily river water temperature registered at selected measurement profiles (the River Noteć and its tributaries) and air temperature has confirmed their considerable dependence during the analysed period. The application of multidimensional statistical modelling, taking into consideration varied methodological criteria, has made it possible to determine the nature of relationships occurring between data series. It was particularly interesting to determine cause-and-effect relationships not only along the water-air axis, but also along the air-water axis, which occur mainly during water freezing and evaporation processes. The application of Granger's causality demonstrated the existence of complex multi-level dependences that are conditioned by the number of variables used in research. When taking into consideration a one-day lag between measurements, Granger's causality was confirmed in two directions, which fact is of considerable importance for forecasting. Namely, this means that forecasting the fluctuations of the temperature of river waters on the basis of changes in air temperature may be more effective when use is made of information from the preceding day.

The results of the analysis have also confirmed the presence of a nonlinear relation between daily river water and air temperature. In all instances, the linear model recreated water temperature variance to a lesser degree than the natural cubic spline model. Differences between these models amounted to approximately $4-5 \%$ and were statistically significant. Also established was a weak, albeit statistically significant correlation of random fluctuations for the same days for both series, i.e. changes in temperature which do not follow from a long-term trend, historical values, or periodicity. This made it possible to confirm the occurrence of short-term connections between water and air temperature. The thermal regime of the researched rivers is impacted first and foremost by the surface exchange of heat with the atmosphere. Locally, the thermal characteristics of river waters may be modified by anthropogenic factors identified in the catchment area and the river valley, which may disturb the continuity of processes and the gradient nature of zones in rivers. In the case of the River Noteć, these factors include the morphological nature of the river valley and the risk of inflow of pollutants, which are the single most important factor contributing to increases in the temperature of flowing waters.

The results obtained constitute a database for reference indications of thermal parameters that are of significance for predicting climate change and for conducting research into the thermal regime of the river. On a regional scale, they may be used to assess the impact of climatic change, while on the local-to analyse anthropogenic influences on the development and nature of the relationship between river water and air temperature. Furthermore, the relations determined between thermal water and air parameters determine the degree of risk for the functioning of aquatic ecosystems represented by habitats and species susceptible to changes in river water temperature. This problem is particularly important in the case of rivers with significant ecological functions (e.g. migration corridors for various species of fishes), among which the Noteć is classified.

The results can be used to determine the qualities of thermal regimes and to predict the temperature of river waters under conditions of climate change. In light of the constant demand for information concerning the thermal regime features of waters in lowland river ecosystems (which are subjected to varying degrees of anthropogenic transformation), the results obtained constitute an important supplementation of databases used to ensure their rational management.

Acknowledgements The present paper is the result of research on thermal conditions of the river water with use of the statistical methods, carried out as part of statutory research at the Department of Hydrology and Water Management of the Institute of Physical Geography and Environmental Planning of the Adam Mickiewicz University in Poznań, Poland. The author would like to thank Szymon Talaga for his help in performing the statistical analyses.

\section{Compliance with ethical standards}

Conflict of interest The authors declare that they have no conflict of interest. 
Open Access This article is distributed under the terms of the Creative Commons Attribution 4.0 International License (http://creativeco mmons.org/licenses/by/4.0/), which permits unrestricted use, distribution, and reproduction in any medium, provided you give appropriate credit to the original author(s) and the source, provide a link to the Creative Commons license, and indicate if changes were made.

\section{References}

Allan JD, Castillo MM (2007) Stream ecology: structure and function of running waters, 2nd edn. Chapman and Hall, New York

Arismendi I, Safeeq M, Dunham JB, Johnson SL (2014) Can air temperature be used to project influences of climate change on stream temperature? Environ Res Lett 9:084015

Arscott DB, Tockner K, Ward JV (2001) Thermal heterogeneity along a braided floodplain river (Tagliamento River, northeastern Italy). Can J Fish Aquat Sci 58:2359-2373

Benyahya L, Caissie D, St-Hilaire A, Ouarda TBM, Bobée B (2007) A review of statistical water temperature models. Can Water Resources J 32:179-192

Bogan T, Mohseni O, Stefan HG (2003) Stream temperatureequilibrium temperature relationship. Water Resources Res 39:1245-1256

Bolker BM, Brooks ME, Clark CJ, Geange SW, Poulsen JR, Stevens MHH, White J-SS (2009) Generalized linear mixed models: a practical guide for ecology and evolution. Trends Ecol Evol $24: 127-135$

Caissie D (2006) The thermal regime of rivers: a review. Freshw Biol 51:1389-1406

Caissie D, El-Jabi N, St-Hilaire A (1998) Stochastic modeling of water temperatures in a small stream using air to water relations. Can J Civ Eng 25(2):250-260

Caissie D, El-Jabi N, Satish MG (2001) Modelling of maximum daily water temperatures in a small stream using air temperatures. $\mathbf{J}$ Hydrol 251:14-28

Caissie D, St-Hilaire A, El-Jabi N (2004) Prediction of water temperatures using regression and stochastic models. In: 57th Canadian water resources association annual congress, Montreal, QC, June 16-18, 2004, Ottawa, Ontario

Caissie D, Satish MG, El-Jabi N (2005) Predicting river water temperatures using the equilibrium temperature concept with application on the Miramichi River catchments (New Brunswick, Canada). Hydrol Process 19:2137-2159

Cameron AC, Trivedi PK (2005) Microeconometrics methods and applications. Cambridge University Press, Cambridge

Conlan K, Lane S, Ormerod S, Wade T (2005) Preparing for climate change impacts on freshwater ecosystems (PRINCE). Environment Agency, Science Report: SC030300/SR. http://llynbriann e-lter.org/wp-content/uploads/2013/01. Accessed 10 Feb 2018

Detto M, Molini A, Katul G, Stoy P, Palmroth S, Baldocchi D (2012) Causality and persistence in ecological systems: a nonparametric spectral Granger causality approach. Am Nat 179:524-535

DeWeber JT, Wagner TA (2014) Regional neural network ensemble for predicting mean daily river water temperature. J Hydrol 517:187-200

Dickey DA, Fuller WA (1981) Likelihood ratio statistics for autoregressive time series with a unit root. Econometrica 49:1057-1072

ETC/ICM (2015) European freshwater ecosystem assessment: crosswalk between the water framework directive and habitats directive types, status and pressures. ETC/ICM technical report 2/2015. European Topic Centre on inland, coastal and marine waters, Magdeburg. http://ecologic.eu/12451. Accessed 10 Feb 2018
Gallice A, Schaefli B, Lehning M, Parlange MP, Huwald H (2015) Stream temperature prediction in ungauged basins: review of recent approaches and description of a new physically-based analytical model. Hydrol Earth Syst Sci 19:3727-3753

Gardner B, Sullivan PJ, Lembo AJ (2003) Predicting stream temperatures: geostatistical model comparison using alternative distance metrics. Can J Fish Aquat Sci 60:344-351

Gelman A, Hill J (2006) Data analysis using regression and multilevel/ hierarchical models. Cambridge University Press, Cambridge

Graf R (2015) Variations of the thermal conditions of the Warta in the profile connecting the Urstromal and gorge sections of the valley (Nowa Wieś Podgórna-Śrem-Poznań) Zmiany termiki wód Warty w profilu łączącym pradolinny i przełomowy odcinek doliny (Nowa Wieś Podgórna-Śrem-Poznań). In: Absalon D, Matysik M, Ruman M (eds) Novel methods and solutions in hydrology and water management. Hydrological Committee PTG, PTG Department, Katowice, pp 177-194

Graf R (2018) Distribution properties of a measurement series of river water temperature at different time resolution levels (based on the example of the Lowland River Noteć, Poland). Water 10:203. https://doi.org/10.3390/w10020203

Graf R, Tomczyk AM (2018) The impact of cumulative negative air temperature degree-days on the appearance of ice cover on a river in relation to atmospheric circulation. Atmosphere 9(6): 204

Graf R, Łukaszewicz JT, Jawgiel K (2018) The analysis of the structure and duration of ice phenomena on the Warta river in relation to thermic conditions in the years 1991-2010 (Analiza struktury i czasu trwania zjawisk lodowych na Warcie na tle warunków termicznych w okresie 1991-2010). Woda-Środowisko Obsz Wiej 18:5-28

Granger CWJ (1988) Some recent developments in a concept of causality. J Econom 39(1-2):199-211

Hadzima-Nyarko M, Rabi A, Šperac M (2014) Implementation of artificial neural networks in modeling the water-air temperature relationship of the river Drava. Water Resources Manag 28(5):1379-1394

Hannah DM, Malcolm IA, Soulsby C, Youngson AF (2004) Heat exchanges and temperatures within a salmon spawning stream in the Cairngorms, Scotland: seasonal and sub-seasonal dynamics. River Res Appl 20:635-652

Hilderbrand RH, Kashiwagi MT, Prochaska AP (2014) Regional and local scale modeling of stream temperatures and spatio-temporal variation in thermal sensitivities. Environ Manag 54:14-22

Hox J (2002) Multilevel analysis: techniques and applications. Lawrence Erlbaum Associates, Publishers, Mahwah

Jackson MC, Loewen CJG, Vinebrooke RD, Chimimba CT (2016) Net effects of multiple stressors in freshwater ecosystems: a metaanalysis. Glob Change Biol 22:180-189

Kędra M, Wiejaczka $Ł$ (2016) Disturbance of water-air temperature synchronisation by dam reservoirs. Water Environ J $30(1-2): 31-39$

Kondracki J (2008) Regional geography of Poland (Geografia regionalna Polski). Scientific Publishing House PWN, Warsaw

Lagergaard Pedersen N, Sand-Jensen K (2007) Temperature in lowland Danish streams: contemporary patterns, empirical models and future scenarios. Hydrol Process 21:348-358

Langan SJ, Johnston L, Donaghy MJ, Youngson AF, Hay DW, Soulsby C (2001) Variation in river water temperatures in an upland stream over a 30-year period. Sci Total Environ 265:195-207

Łaszewski M (2014) Methods of estimating stream water temperature and air temperature relationships-the Świder River case study (Metody określania związków temperatury wody rzecznej i temperatury powietrza na przykładzie rzeki Świder). Prace Geogr $136: 45-60$ 
Letcher BH, Hocking DJ, O'Neil K, Whiteley AR, Nislow KH, O'Donnell MJ (2016) A hierarchical model of daily stream temperature using air-water temperature synchronization, autocorrelation, and time lags. PeerJ 4:e1727

Li H, Deng X, Kim D-Y, Smith EP (2014) Modeling maximum daily temperature using a varying coefficient regression model. Water Resources Res 50:3073-3087

Lisi PJ, Schindler DE, Cline TJ, Scheuerell MD, Walsh PB (2015) Watershed geomorphology and snowmelt control stream thermal sensitivity to air temperature Geophys. Res Lett 42:3380-3388

Liu B, Yang D, Ye B, Berezovskaya S (2005) Long-term open-water season stream temperature variations and changes over Lena River Basin in Siberia. Glob Planet Change 48:96-111

Marszelewski W, Pius B (2018) Relation between air temperature and inland surface water temperature during climate change (19612014): case study of the Polish Lowland. In: Zelenakova M (ed) Water management and the environment: case studies. Springer, Berlin, pp 175-195

Mohseni O, Stefan HG (1999) Stream temperature/air temperature relationship: a physical interpretation. J Hydrol 218:128-141

Mohseni O, Stefan HG, Erickson TR (1998) A nonlinear regression model for weekly stream temperatures. Water Resources Res 34:2685-2692

Morrill JC, Bales RC, Conklin MH (2005) Estimating stream temperature from air temperature: implications for future water quality. J Environ Eng 131:139-146

Napiórkowski MJ, Piotrowski AP, Napiórkowski JJ (2014) Stream temperature forecasting by means of ensemble of neural networks: importance of input variables and ensemble size. In: Schleiss AJ et al (eds) River flow. Taylor \& Francis Group, London

Neumann DW, Rajagopalan B, Zagona EA (2003) Regression model for daily maximum stream temperature. J Environ Eng 7:667-674

Olden JD, Naiman RJ (2010) Incorporating thermal regimes into environmental flows assessments: modifying dam operations to restore freshwater ecosystem integrity. Freshw Biol 55:86-107

Padilla A, Rasouli K, Déry SJ (2015) Impacts of variability and trends in runoff and water temperature on salmon migration in the Fraser River Basin, Canada. Hydrol Sci J. https://doi.org/10.1080/02626 667.2014.892602

Pilgrim JM, Fang X, Stefan HG (1998) Stream temperature correlations with air temperature in Minnesota : implications for climate warming. J Am Water Resources Assoc 34:1109-1121

Piotrowski AP, Napiórkowski JJ (2018) Performance of the air2stream model that relates air and stream water temperatures depends on the calibration method. J Hydrol 561:395-412

Poole C, Berman CH (2001) An ecological perspective on in-stream temperature: natural heat dynamics and mechanisms of humancaused thermal degradation. Environ Manag 27(6):787-802
R Core Team (2015) R: a language and environment for statistical computing. R Foundation for Statistical Computing, Vienna, Austria. http://www.R-project.org. Accessed 10 Feb 2018

Rushworth AM, Peterson EE, Ver Hoef JM, Bowman AW (2015) Validation and comparison of geostatistical and spline models for spatial stream networks. Environmetrics 26:327-338

Sahoo GB, Schladow SG, Reuter JE (2009) Forecasting stream water temperature using regression analysis, artificial neural network, and chaotic non-linear dynamic models. J Hydrol 378:325-342

Sinokrot BA, Stefan HG (1994) Stream water temperature sensitivity to weather and bed parameters. ASCE J Hydraul Eng 120:722-736

Sinokrot BA, Stefan HG, McCormick JH, Eaton JG (1995) Modeling of climate change effects on stream temperatures and fish habitats below dams and near groundwater inputs. Clim Change 30:181-200

Toffolon M, Piccolroaz S (2015) A hybrid model for river water temperature as a function of air temperature and discharge. Environ Res Lett 10:114011. https://doi.org/10.1088/17489326/10/11/114011

Webb BW, Nobilis F (2007) Long-term changes in river temperature and the influence of climatic and hydrological factors. Hydrol Sci 52:74-85

Webb BW, Clack PD, Walling DE (2003) Water-air temperature relationships in a Devon river system and the role of flow. Hydrol Process 17:3069-3084. https://doi.org/10.1002/hyp.1280

Wiejaczka $€$ (2007) Relationship between water temperature in the river and air temperature -on the Ropa River as an example. (Relacje pomiędzy temperaturą wody w rzece a temperatura powietrza - na przykładzie rzeki Ropy). Folia Geogr Geograph Phys 37-38:95-105

Wiejaczka $€$ (2011) Influence of storage reservoir on the relations between the temperature of water in the river and the air temperature (Wpływ zbiornika retencyjnego na relacje między temperatura wody w rzece a temperaturą powietrza). Przegląd Naukowy Inżynieria i Kształtowanie Środowiska 53:183-195

Woś A (2010) The climate of Poland in the second half of the 20th century (Klimat Polski w drugiej połowie 20. Wieku). Scientific Publishing House UAM, Poznan

Younus M, Hondzo M, Engel BA (2000) Stream temperature dynamics in upland agricultural watersheds. J Environ Eng 126:518-526

Żelazny M, Rajwa-Kuligiewicz A, Bojarczuk A, Pęksa Ł (2018) Water temperature fluctuation patterns in surface waters of the Tatra Mts, Poland. J Hydrol 564:824-835. https://doi.org/10.1016/j. jhydrol.2018.07.051

Zhu S, Nyarko EK, Hadzima-Nyarko M (2018) Modelling daily water temperature from air temperature for the Missouri River. PeerJ 6:e4894. https://doi.org/10.7717/peerj.4894 